\title{
A Study on Extent of Adoption of Improved Cultivation Practices by Turmeric Growers in Belagavi District, Karnataka, India
}

\author{
Mutteppa Chigadolli $^{1 *}$, B. Krishnamurthy ${ }^{1}$, H.K. Pankaja ${ }^{2}$ and K. Nishita ${ }^{3}$ \\ ${ }^{1}$ Department of Agricultural Extension, UAS, GKVK, Bengaluru-560065 \\ ${ }^{2}$ Agricultural Extension, Directorate of Extension, Hebbal, UAS, GKVK, Bengaluru \\ ${ }^{3}$ Technical Assistant Karnataka Agricultural Price Commission GoK, Bengaluru
}

*Corresponding author

\begin{tabular}{|c|c|}
\hline & A B S T R A C T \\
\hline Keywords & \multirow{4}{*}{$\begin{array}{l}\text { The present study was conducted during } 2017-18 \text { in Belagavi district of Karnataka to } \\
\text { analyze the extent of adoption of improved cultivation practices by turmeric growers. A } \\
\text { total of } 120 \text { respondents were selected randomly which includes } 60 \text { respondents from } \\
\text { Raibag and Gokaktaluks since production, productivity and area under turmeric was found } \\
\text { to be maximum. The findings of the study revealed that, } 47.50 \text { per cent of turmeric } \\
\text { growers belonged to medium level of overall adoption, followed by high }(32.50 \%) \text { and } \\
\text { low }(20.00 \%) \text { level overall adoption of improved cultivation practices. With respect to } \\
\text { adoption of individual improved turmeric cultivation practices, majority of turmeric } \\
\text { growers fully adopted the land preparation practices }(>84.00 \%) \text {, Mother rhizomes for seed } \\
\text { purpose }(88.33 \%) \text {, recommended variety and planting time }(>85.00 \%) \text {, planting method } \\
(100.00 \%) \text {, intercropping }(84.17 \%) \text {, FYM-Farm Yard Manure }(89.17 \%) \text {, Nitrogen and } \\
\text { Potassium application }(98.33 \%) \text {, Number of irrigations to turmeric }(83.33 \%) \text {, Manual } \\
\text { weeding }(71.66 \%) \text {, Maturity and Harvesting practices }(>75.00 \%) \text {, traditional method of } \\
\text { preservation of rhizomes }(81.67 \%) \text { and post-harvest management practices }(>80.00 \%) \text {. }\end{array}$} \\
\hline $\begin{array}{l}\text { Extent of adoption, } \\
\text { Turmeric, Turmeric } \\
\text { growers and } \\
\text { Improved } \\
\text { cultivation practices }\end{array}$ & \\
\hline Article Info & \\
\hline $\begin{array}{l}\text { Accepted: } \\
\text { 20 February } 2019 \\
\text { Available Online: } \\
\text { 10 March } 2019\end{array}$ & \\
\hline
\end{tabular}

\section{Introduction}

India is known as 'Land of Spices'. India is the largest producer, consumer and exporter of spices in the world followed by China. India utilizes 90 per cent of its production for domestic consumption. About 109 spices are notified all over world where India is single country grows 63 among them. Share of spices in total agricultural export of India is about six per cent. India's share of world spice trade is about 45 to 50 per cent by volume and 25 to 30 per cent by value (Anonymous 2014).
In India turmeric is growing in as many as 25 states and among them Telangana, Andhra Pradesh, Karnataka, Tamil Nadu and Gujarat are the leading producers of turmeric. India had nearly 1.94 lakh hectares under cultivation of turmeric with a total production of 10.52 lakh tons during the year 2016-17. Telangana topped both in area and production with 50,000 hectares and 2,55,000 tons production during the year 2016-17 followed by Tamil Nadu in area with 29,306 hectares and Andhra Pradesh in production with 134,122 tons (Anonymous 2017). 
In Karnataka, turmeric was cultivated in an area of 14,994 hectares with a production of 76,490 tons during the year 2016-17. Belagavi district is second largest turmeric producing district with an area of 3,498 hectares and production of 33,861 tons of turmeric only after Chamarajanagar district with an area of 8,230 hectares and production of 36,031 metric tons of turmeric. Mysuru (3,130 ha and 22,065 metric tons) Bagalkot (2,585 ha and 12,912 metric tons) districts stood third and fourth rank in both area and production of turmeric in the state during the year 2015-16. (Anonymous 2016)

Knowing about the improved practices in turmeric cultivation and their adoption is need of hour, since turmeric is an input intensive crop and it drains the nutrients more readily. Adoption of these improved practices is important to sustain the fertility soil and to increase the potentiality of turmeric production. The improved practices in turmeric cultivation are land preparation, rhizomes selection and treatment, planting of rhizomes, mulching, integrated nutrient management, water management, pest and disease management, weed management, maturity and harvesting, post-harvest management and processing needs to be adopted to obtain better productivity.

Even though, there are number of improved turmeric cultivation practices which were identified and recommended to maximize production, the growers are not adopting the improved and recommended cultivation practices. Hence, the study will help the extension personnel's, other line departments and policy makers to develop the strategies to bridge the adoption gap and how to reach the unreached farmers. Hence, the current study is taken up with the following specific objective: To assess the Extent of Adoption of improved cultivation practices by turmeric growers.

\section{Materials and Methods}

The existing study was conducted using the "Ex-post facto" research design. This design was found suitable and appropriate for this research study as the phenomenon/event that has already been occurred or happened. This research study was carried out in the Belagavi district of Karnataka as it stands in the second position in both area under turmeric and production of turmeric and first in productivity of turmeric. Among ten taluks in Belagavi district Raibag and Gokak are the two leading taluks in both area and production of turmeric. Hence these two taluks are purposively selected for the study. From each taluk three villages were selected randomly which have maximum area under turmeric cultivation which were identified by consulting with the Raitha Sampark Kendra (RSK). From each village, 20 turmeric growing farmers were selected randomly for the study. Data collection was made through personal interview method. Thus, the final sample comprises of 120 respondents spread over in three different villages from each taluk. The extent of adoption is measured using the index developed by Sengupta (1967). The data collected was analyzed using Mean, Standard deviation, frequency and percentage which were found appropriate.

\section{Results and Discussion}

\section{Overall adoption level of turmeric growers with respect to improved cultivation practices}

Table 1 indicates the distribution of turmeric cultivators with respect to their overall adoption of improved turmeric cultivation practices shows that 47.50 per cent of turmeric farmers were in medium level adoption, 32.50 per cent of turmeric farmers had high extent of adoption and it is also noticed that only 20.00 per cent had low level adoption of improved 
turmeric cultivation practices. It is measured using the scale developed by the Sengupta (1967).

Nearly half of the turmeric farmers had medium extent of adoption of improved cultivation practices because of nonavailability of inputs timely whenever required like quality seed material, biofertilizers, non-availability of farm yard manure etc. With respect to the integrated nutrient management, pest and disease management and weed management more than half of turmeric growers were in partial adoption category i.e., they were applying more than recommended quantities except farmyard manure and bio-fertilizers. Turmeric growers opinion regarding more usage than recommended quantity, the reply is that if recommended quantities were applied then the expected yield will not be obtained. Some of the turmeric growers did not use the recommended inputs provided by the private agencies due to high cost of inputs. The findings of this study are following the research findings of Ganeshprasad (2006) and Chethan (2011).

Practice-wise adoption level of improved cultivation practices by turmeric growers of Belagavi district

The results in Table 2, represents different levels of adoption behaviour of turmeric growers such as full adoption, partial adoption and non-adoption, with respect to individual improved turmeric cultivation practices.

\section{Land preparation}

Most of the turmeric growing farmers (90.83, 86.67, and $84.17 \%$ ) fully adopted the practices like clean and deep tillage, cultivating turmeric in recommended soil and 3-4 times of ploughing the land to bring fine tilth for planting rhizomes. The reason for adoption of these practices are the low cost of these practices and their simplicity which can be practiced by making use of mere knowledge and their own resources without reliance on any external agency.

\section{Rhizomes selection and treatment}

Majority $(88.33 \%)$ of turmeric growers fully adopted the mother rhizomes for seed purpose and nearly three fourth $(73.33 \%)$ of them fully adopted the treatment of rhizomes before planting with mancozeb or Trichoderma. The farmers adopted these practices because the turmeric is more prone to shoot borer and rhizome rot hence in order to prevent and control these problems they followed the rhizomes treatment and used mother rhizomes for planting because they give a greater number of tillers.

\section{Planting of rhizomes}

Cent per cent of the turmeric growers fully adopted the either ridge or furrow or raised bed method of planting and spacing. Majority $(85.83,85.00$, and $84.17 \%)$ of them wholly adopted the practices such as recommended variety, planting rhizomes in May/June month and intercropping with the crops like brinjal, maize, vegetables, chilli etc. Little less than half $(48.33 \%)$ of the turmeric growing farmers had partially adopted recommended quantity of rhizomes/ seed rate of 10 quintals per acre for planting. It is unimaginary to observe that 93.33 per cent of turmeric farmers had not adopted crop rotation of turmeric with recommended pulse crops. Farmers adopted recommended varieties as these enhances the production and also increases its monetary value due to high curcumin content. They adopted intercropping to earn extra earnings and also for the fodder purpose to cattle. They used rhizomes more than suggested quantity because of poor germination of buds. It is also ascertained that 
they practiced crop rotation with sugarcane due to high residuals of fertilizers in soil and also ownership of large land property, they shifted the turmeric crops with sugarcane.

\section{Mulching}

None of the farmers had adopted the mulching practice in turmeric. This is because of the abundant availability of the water from the canal and river basin. Mulching is not practiced by any of the farmers due to the fact of plentiful availability of water from the river basins, canals and bore-wells. Other reason is that these farmers were practicing intercropping of vegetables and fodder crops like maize.

\section{Integrated nutrient management}

All the farmers adopted the FYM application. Majority of the turmeric growers $(80.83,65.00$ and $57.50 \%$ ) had partial level of adoption of application of recommended quantity of NPK per acre, FYM application per acre and micronutrients like Zinc Sulphate $\left(\mathrm{ZnSo}_{4}\right)$ application at $5 \mathrm{~kg}$ per acre per year respectively. Majority of the turmeric farmers (98.33, 89.17 and $78.33 \%$ ) had fully adopted the split fertigation of nitrogenous fertilizers and basal application of $\mathrm{K}$ fertilizer, right time of application of FYM and phosphorous application respectively. Considerable number of turmeric growers $(42.50 \%)$ had completely adopted the application of neem cake or coir pith at the rate of $100 \mathrm{~kg}$ per acre. Nearly four fifth $(82.50 \%)$ of the respondents had not applied the bio-fertilizers. This trend of results is due to the reason that farmers applying the fertilizers in more than recommended quantity with intent of obtaining higher yield and also non-availability of FYM to apply. It was also observed that many of the turmeric farmers had not adopted bio-fertilizer application because of lack of knowledge and nonavailability of bio-fertilizer so timely and locally.

\section{Water management}

Majority of farmers $(83.33 \%)$ had completely adopted the 38 to 42 times (red sandy soil) and 25 to 30 (black soil) times of irrigation. 69.17 per cent of turmeric growers had not adopted the recommended methods of irrigation such as drip irrigation method and alternate row wetting and drying instead they adopted the flooding method of irrigation. The majority of the farmers had not adopted the modern and effective irrigation methods like drip and alternate row wetting and drying of irrigation because of plentiful availability of water from river basins, canals and borewells.

\section{Pest and Disease management}

From the Table 2 it is observed that more than half of turmeric growers $(62.50,61.67,58.33$, 51.67 and $50.83 \%$ ) had partially adopted the management measures of rhizome rot disease, root borer and shoot borer, leaf spot disease and rhizome scale disease. About 94.17 per cent of farmers had not adopted management measures of other disease occurred other than the major pests and diseases and majority of the farmers $(64.17 \%)$ neglected and not adopted the management practices of thrips. The farmers adopted these practices partially because they use the chemicals in more than recommended dosage in order to control the pests and diseases more efficaciously and they were suggested by the private dealers to use the more concentrated pesticide or insecticide. Farmers neglected the management of other disease and pest since by time of their occurrence turmeric crop would reach the harvesting stage.

\section{Weed management}

Majority of the turmeric growers (71.66\%) had completely followed manual weeding at monthly interval for three to four times and also found that majority $(54.17 \%)$ of the 
Turmeric, farmers were not adopted the chemical weed control methods. This trend of results is due to the reality that farmers are growing the vegetables and other crops with turmeric as the inter-crop and they prefer to follow manual weeding rather than chemical weeding. Another reason for not practicing chemical weed control method is that the next crop will not come properly and it also reduces the soil fertility.

\section{Maturity and harvesting}

75.83 per cent of turmeric growers had completely adopted the appropriate stage of turmeric harvesting and leaving of rhizomes in the field after cutting the leaves of turmeric plant. Cent per cent of them completely adopted the manual digging method for the turmeric harvesting and nobody followed the tractor drawn harvester. These results are due to the reason that farmers maintain the monthwise records until its harvested. All the farmers adopted the manual digging method of harvesting because of non-availability of the tractor drawn harvesters in that region.

\section{Preservation of rhizomes}

Majority of the turmeric farmers $(81.67 \%)$ had completely adopted the traditional method of rhizomes preservation and none of them had adopted the modern method of rhizome preservation. This trend of result is due to the fact that traditional method (rhizome preservation under shade of a tree and covering with leaves of turmeric), which is easy method and no cost is involved in this method compared to modern method.

\section{Post-harvest management/processing}

Majority of turmeric growers $(89.17,85.83$, $85.00,81.67$ and $79.17 \%$ ) had fully adopted the improved practices such as drying of boiled turmeric for 21 days under sunlight, grading of turmeric into 3-4 classes, boiling of mother rhizomes and finger rhizomes separately, around 30 minutes of boiling and polishing of turmeric. Exactly 58.33 per cent of farmers had not adopted the uniform (3-5 inches) spreading of boiled rhizomes for drying purpose under sunlight. This is due to the simplicity of the practices and these are the important practices in turmeric in order to improve the quality as well as these determine quality and price of the produce. Mother rhizomes are marketed immediately after harvest without boiling to the wholesaler's whereas finger rhizomes were boiled using the steam boilers because they take less time and less fuel to boil the rhizomes. Majority of them not followed uniform spreading of boiled rhizomes because turmeric farmers were unaware about this practice.

Table.1 Overall extent of adoption of improved cultivation practices by turmeric growers $(\mathrm{N}=$ 120)

\begin{tabular}{|c|l|c|c|}
\hline \multirow{2}{*}{ Sl. No. } & \multirow{2}{*}{ Extent of adoption } & \multicolumn{2}{|c|}{ Turmeric growers } \\
\cline { 3 - 4 } & & Number & Per cent \\
\hline $\mathbf{1}$ & Low & 24 & 20.00 \\
\hline $\mathbf{2}$ & Medium & 57 & 47.50 \\
\hline $\mathbf{3}$ & High & 39 & 32.50 \\
\hline & Total & 120 & 100.00 \\
\hline
\end{tabular}

Mean=52.51; Standard deviation $=6.46$ 
Table.2 Practice-wise extent of adoption of improved cultivation practices by turmeric growers $(\mathrm{N}=120)$

\begin{tabular}{|c|c|c|c|c|c|c|c|}
\hline \multirow{3}{*}{$\begin{array}{l}\text { Sl. } \\
\text { No. }\end{array}$} & \multirow{3}{*}{$\begin{array}{c}\text { Components of improved cultivation } \\
\text { practices }\end{array}$} & \multicolumn{6}{|c|}{ Extent of adoption } \\
\hline & & \multicolumn{2}{|c|}{$\begin{array}{l}\text { Complete } \\
\text { Adoption }\end{array}$} & \multicolumn{2}{|c|}{$\begin{array}{c}\text { Partial } \\
\text { Adoption }\end{array}$} & \multicolumn{2}{|c|}{ Non-adoption } \\
\hline & & No & $\%$ & No & $\%$ & No & $\%$ \\
\hline I & \multicolumn{7}{|c|}{ Land preparation } \\
\hline 1 & Clean and deep tillage practice & 109 & 90.83 & - & - & 11 & 9.17 \\
\hline 2 & 3-4 times ploughing to bring fine tilth & 101 & 84.17 & - & - & 19 & 15.83 \\
\hline 3 & Type of soil you cultivate the turmeric & 104 & 86.67 & - & - & 16 & 13.33 \\
\hline II & \multicolumn{7}{|c|}{ Rhizome selection and treatment } \\
\hline 4 & $\begin{array}{l}\text { Treatment of rhizomes (Mancozeb@ } \\
0.3 \% \text { or Trichoderma) }\end{array}$ & 88 & 73.33 & - & - & 32 & 10.84 \\
\hline 5 & Mother rhizomes used for seed purpose & 106 & 88.33 & - & - & 14 & 11.67 \\
\hline III & \multicolumn{7}{|c|}{ Planting of rhizomes } \\
\hline 6 & $\begin{array}{l}\text { Quantity of rhizomes used per acre for } \\
\text { planting }\end{array}$ & 62 & 51.67 & 58 & 48.33 & - & - \\
\hline 7 & Variety cultivated & 103 & 85.83 & - & - & 17 & 14.17 \\
\hline 8 & Time of planting & 102 & 85.00 & - & - & 18 & 15.00 \\
\hline \multirow[t]{2}{*}{9} & Method of planting practiced & 120 & 100.00 & - & - & - & - \\
\hline & $\begin{array}{l}\text { a) Ridge and furrow } \\
\text { b) Raised bed }\end{array}$ & $\begin{array}{c}106 \\
14\end{array}$ & $\begin{array}{l}88.33 \\
11.67\end{array}$ & $\begin{array}{l}- \\
-\end{array}$ & $\begin{array}{l}- \\
-\end{array}$ & - & $\begin{array}{l}- \\
-\end{array}$ \\
\hline 10 & Intercropping & 101 & 84.17 & - & - & 19 & 15.83 \\
\hline 11 & Crop rotation in turmeric & 8 & 6.67 & - & - & 112 & 93.33 \\
\hline IV & \multicolumn{7}{|c|}{ Mulching } \\
\hline 12 & Material used for mulching in turmeric & - & - & - & - & 120 & 100.00 \\
\hline 13 & $\begin{array}{l}\text { Quantity of raw material is required for } \\
\text { mulching }\end{array}$ & - & - & - & - & 120 & 100.00 \\
\hline 14 & Time of mulching & - & - & - & - & 120 & 100.00 \\
\hline $\mathbf{V}$ & \multicolumn{7}{|c|}{ Integrated Nutrient Management } \\
\hline 15 & $\begin{array}{l}\text { Quantity of application of FYM to } \\
\text { turmeric (10qtl/ac) }\end{array}$ & 29 & 24.17 & 78 & 65.00 & 13 & 10.83 \\
\hline 16 & Time of application of FYM & 107 & 89.17 & - & - & 13 & 10.83 \\
\hline 17 & Quantity of Biofertilizer application & 21 & 17.50 & - & - & 99 & 82.50 \\
\hline 18 & $\begin{array}{l}\text { Quantity of Neem cake/coir pith used } \\
(100 / 25 \mathrm{~kg} / \mathrm{acre})\end{array}$ & 51 & 42.50 & 28 & 23.33 & 41 & 34.17 \\
\hline 19 & Recommended NPK dosage per acre & 23 & 19.17 & 97 & 80.83 & - & - \\
\hline 20 & Time of phosphorous application & 94 & 78.33 & - & - & 26 & 21.67 \\
\hline 21 & Time of $\mathrm{N}$ and $\mathrm{K}$ application & 118 & 98.33 & - & - & 2 & 1.67 \\
\hline 22 & Quantity of micronutrients applied & 20 & 16.67 & 69 & 57.50 & 31 & 25.83 \\
\hline VI & \multicolumn{7}{|c|}{ Water management } \\
\hline 23 & Number of irrigations & 100 & 83.33 & - & - & 20 & 16.67 \\
\hline 24 & Method of irrigation & 37 & 30.83 & - & - & 83 & 69.17 \\
\hline VII & \multicolumn{7}{|c|}{ Pest and disease management } \\
\hline 25 & Management and control of the pests in & 13 & 10.83 & 74 & 61.67 & 33 & 27.50 \\
\hline
\end{tabular}




\begin{tabular}{|c|c|c|c|c|c|c|c|}
\hline & $\begin{array}{l}\text { turmeric } \\
\text { a) Shoot and Root borer (Neem } \\
\text { cake@100kg/acre or Carbofuron 3G } \\
\text { granules @25kg/ha at planting time) }\end{array}$ & & & & & & \\
\hline & $\begin{array}{l}\text { b) Rhizome scale (Melathion@2ml/lit or } \\
\text { Quinolpos / Posolin@2ml/lit) }\end{array}$ & 20 & 16.66 & 62 & 51.67 & 38 & 31.67 \\
\hline & $\begin{array}{l}\text { c) Thrips (Dimethioate@1.7ml/ lit or } \\
\text { Phoshpomidan@0.5ml / lit) }\end{array}$ & 3 & 2.50 & 40 & 33.33 & 77 & 64.17 \\
\hline & d) Any other (Sutukuroga) & - & - & 7 & 5.83 & 113 & 94.17 \\
\hline \multirow[t]{3}{*}{26} & $\begin{array}{l}\text { Management and control of diseases in } \\
\text { turmeric } \\
\text { a) Leaf blotch (Mancozeb@2gm/lit or } \\
\text { Spray Carbendizem@0.1\%) }\end{array}$ & 43 & 35.83 & 61 & 50.83 & 16 & 13.33 \\
\hline & $\begin{array}{l}\text { b) Rhizome rot (Dip rhizomes in } 0.3 \% \\
\text { Captan or spray bordeaux mixture) }\end{array}$ & 10 & 8.33 & 75 & 62.50 & 35 & 29.17 \\
\hline & c) Leaf spot (Spray Mancozeb@2gm/ lit) & 23 & 19.17 & 70 & 58.33 & 27 & 22.50 \\
\hline VII & \multicolumn{7}{|c|}{ Weed management } \\
\hline 27 & Manual weeding & 86 & 71.66 & - & - & 34 & 28.34 \\
\hline 28 & Chemical weed control methods & 15 & 12.50 & 40 & 33.33 & 65 & 54.17 \\
\hline IX & \multicolumn{7}{|c|}{ Maturity and Harvesting } \\
\hline 29 & Harvesting stage of the turmeric & 91 & 75.83 & - & - & 29 & 24.17 \\
\hline 30 & Method of harvesting & 120 & 100.00 & - & - & - & - \\
\hline 31 & $\begin{array}{l}\text { Rhizomes left in the field after cutting } \\
\text { leaves and before boiling }\end{array}$ & 91 & 75.83 & - & - & 29 & 24.17 \\
\hline $\mathbf{X}$ & \multicolumn{7}{|c|}{ Preservation of seed rhizomes } \\
\hline \multirow[t]{2}{*}{32} & $\begin{array}{l}\text { Method used for seed preservation } \\
\text { a) Traditional method }\end{array}$ & 98 & 81.67 & - & - & 22 & 18.33 \\
\hline & b) Modern method & - & - & - & - & 120 & 100.00 \\
\hline $\mathbf{X I}$ & \multicolumn{7}{|c|}{ Post-harvest Management/Processing } \\
\hline 33 & $\begin{array}{l}\text { Boiling of finger and mother rhizomes } \\
\text { separately }\end{array}$ & 102 & 85.00 & - & - & 18 & 15.00 \\
\hline 34 & $\begin{array}{l}\text { Time required for boiling by steam } \\
\text { boiling method }\end{array}$ & 98 & 81.67 & - & - & 22 & 18.33 \\
\hline 35 & $\begin{array}{l}\text { Spreading of the boiled rhizomes for } \\
\text { drying }\end{array}$ & 50 & 41.67 & - & - & 72 & 58.33 \\
\hline 36 & Drying of boiled turmeric under sunlight & 107 & 89.17 & - & - & 13 & 10.83 \\
\hline 37 & Polishing of the turmeric & 95 & 79.17 & - & - & 25 & 20.83 \\
\hline 38 & Grading of turmeric & 103 & 85.83 & - & - & 17 & 14.17 \\
\hline
\end{tabular}

In conclusion most $(48.00 \%)$ of the turmeric farmers belonged to medium adoption category. Therefore, it is necessary for keeping the farmers updated about new improved practices and there is a scope for improving the level of adoption among the farmers, who have low and medium adoption of improved practices by providing updated and recent information. Hence farmers need to be convinced about the positive consequences and benefits of adopting improved turmeric cultivation practices in 
order to enhance the rate of adoption.

\section{References}

Anonymous, 2014, Area, Production and productivity of major spices in India. Spice Board, India, Ministry of Agriculture and farmers welfare, GoI.

Anonymous, 2016, Horticulture crop statistics of Karnataka state at a glance 2015-16. Directorate of Horticulture Lalbagh, Bengaluru.

Anonymous, 2017, Area, Production and productivity of major spices in India.Spice Board, India, Ministry of Agriculture and farmers welfare, Govt of India.

Chethan, M. G., 2011, A study on knowledge and adoption of cardamom cultivation practices by the farmers of Chikmagalur district. M. Sc. (Agri.) Thesis, Univ. Agric. Sci., Dharwad.

Ganeshprasad, T. S., 2006, An analysis of adoption, marketing and constraints of turmeric grower's in Chamarajanagar district. M. Sc. (Agri.) Thesis, Univ. Agric. Sci., Bengaluru.

Sengupta, T., 1967, A simple adoption for selection for high yielding varieties programme on rice. Indian Journal of Extension Education., 3:107-115.

\section{How to cite this article:}

Mutteppa Chigadolli, B. Krishnamurthy, H.K. Pankaja and Nishita, K. 2019. A Study on Extent of Adoption of Improved Cultivation Practices by Turmeric Growers in Belagavi District, Karnataka, India. Int.J.Curr.Microbiol.App.Sci. 8(03): 2411-2418. doi: https://doi.org/10.20546/ijcmas.2019.803.284 